\title{
KEDUDUKAN SANKSI PIDANA MATI PADA TINDAK PIDANA NARKOTIKA \\ (Kajian Kebijakan Hukum Pidana)
}

\author{
Ngadikun, Hidayatullah dan Iskandar Wibawa \\ Email : ngadikun1965@gmail.com, hidayatullah@umk.ac.id, \\ iskandar.wibawa@yahoo.com \\ Fakultas Hukum Universitas Muria Kudus
}

\begin{abstract}
ABSTRAK
Penelitian mengenai "Kedudukan Sanksi Pidana Mati pada Tindak Pidana Narkotika" (Kajian Kebijakan Hukum Pidana) dilakukan dengan tujuan untuk mendeskripsikan dan menganalisa secara mendalam mengenai kebijakan sanksi pidana mati pada tindak pidana narkotika dan penerapan sanksi pidana mati terhadap pelaku tindak pidana narkotika. Metode penelitian yang digunakan yaitu yuridis normatif dan menggunakan sumber hukum primer, sekunder dan tersier, dengan menerapkan beberapa jenis pendekatan yaitu pendekatan perundang-undangan dan pendekatan kasus. Keseluruhan sumber hukum dianalisis secara penalaran dan sistematik. Berdasarkan hasil penelitian yang telah dilakukan dapat diketahui Kedudukan Sanksi Pidana Mati pada Tindak Pidana Narkotika" (Kajian Kebijakan Hukum Pidana). Negara Indonesia masih mempertahankan menerapkan sanksi pidana mati, sebagai upaya atau benteng terakhir terhadap pemidanaan. Sanksi pidana mati diterapkan pada kejahatan narkotika termasuk pembuat, bandar dan pengedar. Kejahatan narkotika bagi pembuat, bandar dan pengedar merupakan kejahatan yang berat, serius dan mengacam kehidupan manusia. Jika sanksi pidana mati dihapuskan maka benteng terakhir untuk pemidanan tidak ada. Dari hasil penelitian diharapkan dapat memberikan sumbangan guna referensi atau pertimbangan dalam penyelesaian tindak pidana narkotika atau kasus-kasus yang lain yang diancam dengan sanksi pidana mati.
\end{abstract}

Kata Kunci : Kebijakan Hukum, Pidana Mati, Tindak Pidana Narkotika 


\section{PENDAHULUAN}

Tuhan Yang Maha Esa menganugerahi manusia akal budi dan nurani. Manusia mempunyai derajad yang luhur. Manusia mempunyai budi pekerti dan karsa yang merdeka sendiri. Semua orang sebagai manusia memiliki martabat dan derajat yang sama dan dengan demikian memiliki hak-hak dan kewajiban-kewajiban yang sama. ${ }^{23}$ Hak - hak dasar tersebut disebut Hak Asasi Manusi (HAM) dituangkan dalam Undang - Undang Dasar Republik Indonesia Tahun 1945 kemudian disebut ( UUD NRI Tahun 1945 ) : Pasal 28I angka (1) Hak untuk hidup, hak untuk tidak disiksa, hak kemerdekaan dan hati nurani, hak beragama, hak untuk tidak diperbudak, hak untuk diakui sebagai pribadi di hadapan hukum, dan hak untuk tidak dituntut atas dasar hukum yang berlaku surut adalah hak asasi manusia yang tidak dapat dikurangi daalam keadaan apaun. Pasal 28J :

Angka (1) ; Setiap manusia wajib menghormati hak asasi manusia orang lain dalam tertib kehidupan bermasyarakat, berbangsa, dan bernegara.

Angka (2) ; Dalam menjalani hak dan kebebasannya, setiap orang wajib tunduk kepada pembatas yang ditetapkan dengan undang-undang dengan maksut semata-mata untuk menjamin pengakuan serta penghormatan hak dan kebebasan orang lain dan untuk memenuhi tuntutan yang adil sesuai dengan pertimbangan moral, nilai nilai agama,

23 A. Gunawan Setiardja, Hak-Hak Asasi Manusia Berdasarkan Ideologi Pancasila, Penerbit Kanisius, Yogyakarta, 1993, hlm. 73 keamanan, dan ketertiban umum dalam suatu masyarakat demokratis.

Kebebasan dasar dan hak-hak dasar itulah yang disebut hak asasi manusia yang melekat pada manusia secara kodrati sebagai anugerah Tuhan Yang Maha Esa. Pengingkaran terhadap hak tersebut berarti mengingkari martabat kemanusiaan. Oleh karena itu, negara, pemerintah, atau organisasi apapun dan siapapun mengemban kewajiban untuk mengakui dan melindungi serta menghormati hak asasi manusia pada setiap manusia tanpa kecuali. ${ }^{24}$

Pasca reformasi ini Indonesia masih melaksanakan pembaharuan di bidang hukum, terutama hukum pidana. Lebih khusus lagi kebijakan hukum pidana yang kemarin ramai diperbincang tentang pidana mati tindak pidana narkotika. Hampir semua media menyiarkan berita tentang sanksi pidana mati terhadap tindak pidana narkotika. Pihak setuju dan yang tidak, saling menyampaiakan argumentasi untuk memperkuat pendapatnya. Perbedaan pandangan terhadap sanksi pidana mati dilatarbelakangi oleh berbagai macam alasan.

Pihak yang setuju terhadap pidana mati di antaranya :

"Dilihat dari pokok pemikiran yang lebih menitik bertkan pada perlindungan kepentingan masyarakat, maka wajar konsep tetap mempertahankan jenis-jenis sanksi pidana yang berat, yaitu pidana mati dan penjara seumur hidup. Namun pidana mati di dalam konsep tidak

${ }^{24}$ Bismar Siregar, "Ham Hukum Mati dan Pandangan Bismar", http://busineslaw.business. binus.ac.id, diposting oleh Besar, 28 Januari 2015, hlm. 1 
dimasukkan dalam deretan "pidana pokok", dan ditempatkan tersendiri sebagai jenis pidana yang bersifat khusus atau eksepsional. Pertimbangan utama digesernya kedudukan pidana mati itu didasarkan pada pemikiran , bahwa dilihat dari tujuan pemidanaan dan tujuan diaadakan / digunakan hukum pidana (sebagai salah satu sarana " kebijakan kriminal” dan “ kebijakan sosial"). Pidama mati hakikatnya memang bukanlah sarana utama (sarana pokok) untuk mengatur, menertibkan, dan memperbaiki masyarakat. Pemikiran demikian dapat diidentikkan dengan sarana " amputasi " atau " operasi" di bidang kedokteran yang pada hakekatnya juga bukan sarana / obat yang utama, tetapi hanya merupakan upaya perkecualian sebagai sarana /obat terkhir",25

Pihak yang kontra menyatakan :

"Buat sebagian orang hukuman mati itusah apa lagi untuk penjahat narkoba atau bon Bali. Sikap ini menafikan konstitusi. Kalau demikian apa artinya konstitusi sebagai hukum dasar tertinggi ? Apa artinya kita meratifikasi Covenan on Civil and Polkitical Rights

?. Keyakinan agama dan politik sering mendikte sikap dan inilah yang terjadi dengan hukuman mati.) ${ }^{26}$ “ Hak itu tak diberikan oleh negara, hak itu tak diberikan oleh kostitusi, hak itu ada ketika seorang anak manusia menghembuskan nafasnya yang pertama ketika dia lahir sebagai manusia Negara bisa tidak ada, tetapi

25 Barda Nawawi Arif, "Bunga Rampai Kebijakan Hukum Pidana”, Kencana Prenadamedia Group, Jakarta, 2014, hlm. 94

${ }^{26}$ Todung Mulya Lubis, Kontroversi Hukuman Mati, PT. Kompas Media, Jakarta, 2009, hlm. 12. hak untuk hidup itu aka selalu ada. Jadi sumber 'hak untuk hidup' bukanlah negara. Negara bukan tidak penting. Negara memainkan perang yang sangat penting sebagai penjaga dan penjamin 'hak untuk hidup' seperti yang ditulis dalam Pasal 28A UUD NRI 1945 yang berbunyi :

Setiap orang berhak untuk hidup serta berhak unguk mempertahankanhidup dan kehidupan. Selanjutnya hak untuk hidup ini oleh Pasal 28 I ayat 1 dirumuskan sebagai hak asasi manusia yang tidak dikurangi dalam keadan apapun, atau apa yang dikenal dalam literatur hak asasi manusia sebagai nonderogable human right. $)^{27}$

Berdasarkan latar belakang di atas, dapat dirumuskan permasalahan :

1. Bagaimana kebijakan hukum pidana mempertahankan sanksi pidana mati terhadap pidana narkotika di Indonesia?

2. Bagaimana penerapan sanksi pidana mati terhadap pelaku tindak pidana narkotika?

\section{METODE PENELITIAN}

Penulisan dan penelitian ini dengan judul "Kedudukan Sanksi Pidana Mati Pada Tindak Pidana Narkotika“ (Kajian Kebijakan Hukum Pidana) menggunakan penelitian hukum yuridis normatif yaitu penelitian yang meneliti bahan-bahan hukum atau kajian kepustakaan.

\section{HASIL PENELITIAN DAN PEMBAHASAN}

\section{A. Kebijakan Sanksi Pidana Mati Pada Tindak Pidana Narkotika}

Tindak pidana narkotika sekarang tidak lagi dilakukan oleh perseorangan

${ }^{27}$ Ibid, hal. 30 
melainkan dilakukan secara bersamasama, bahkan merupakan kejahatan yang terorganisasi, suatu sindikat yang jaringannya sangat luas. Tindak Pidana Narkotika merupakan tindak pidana yang berat dan serius serta sangat membahayakan kehidupan manusia, masyaraakat, bangsa dan negara. Penyalahgunaan narkotika mendorong adanya pembuatan dan peredaran gelap. Peredaran gelap narkotika didefinikan dalam Pasal 1 butir 6 UU No. 35 Tahun 2009 tentang Narkotik adalah : Peredaran Gelap Narkotika dan Prekursor Narkotika adalah setiap kegiatan atau serangkaian kegiatan yang dilakukan secara tanpa hak atau melawan hukum yang ditetapkan sebagai tindak pidana Narkotika dan Prekursor Narkotika. Bangsa Indonesia telah melakukan upaya pencegahan pembuatan dan peredaran gelap narkotika.

Upaya pencegahan tersebut melalui Sidang Umum Majelis Permusyawaratan Rakyat Republik Indonesia Tahun 2002 melalui Ketetapan Majelis Permusyawaratan Rakyat Republik Indonesia Nomor VI/MPR/2002 untuk melakukan perubahan atas Undang-Undang Nomor 22 Tahun 1997 menjadi Undang Undang nomor 35 tahun 2009 tentang Narkotika. Undang-Undang tindak pidana narkotika tersebut dirubah dengan Undang- Undang Nomor 35 tahun 2009 tetang Narkotika, diundangkan pada tanggal 12 Oktober 2009. Undang Undang yang baru mengatur upaya pemberantasan terhadap tindak pidana Narkotika melalui pemberatan ancaman pidana denda, pidana penjara 20 tahun, pidana seumur hidup, dan pidana mati. Indonesia saat ini sudah dalam keadaan darurat nakotika. Penjahat narkotika seakan tidak peduli akan ancaman sanksi pidananya. Ancaman sanksi pidana mati adalah hukuman yang paling berat dengan harapan membuat jera bagi pelaku lain. Selama hukum diterapkan secara adil dan konsisten pasti masyarakat akan merasakan keadilan, kepastian dan kemanfatan.

Kebijakan hukum pidana terhadap tindak pidana Narkotika yang dapat diancam sanksi pidana mati menurut UU No. 35 tahun 2009 tentang Narkotika antara lain :

a. Berlakunya hukum pidana menurut tempat diperluas dengan Pasal 145 UU tersebut yang berbunyi :

Setiap orang yang melakukan tindak pidana Narkotika dan/atau tindak pidana Prekursor Narkotika sebagaimana dimaksud dalam Pasal 111, Pasal 112, Pasal 113, Pasal 114, Pasal 115,Pasal 116, Pasal 117, Pasal 118, Pasal 119, Pasal 120, Pasal121, Pasal 122, Pasal 123, Pasal 124, Pasal 125, Pasal 126,Pasal 127 ayat (1), Pasal 128 ayat (1), dan Pasal 129 di luarwilayah Negara Republik Indonesia diberlakukan juga ketentuan UU ini.

b. Perbuatan tanpa hak dan melawan hukum memproduksi, mengimpor, mengekspor, atau menyalurkan narkotika golongan I, II, III (Pasal 113,118,123).

Dari Pasal-Pasal Undang-Undang Narkotika yang mengatur sanksi pidana mati diberikan terhadap kejahatan atau perbuatan yang diberikan sanksi pidana mati pada dasarnya merupakan kejahatan berat dan serius, sangat membahayakan kehidupan manusia, merusak generasi bangsa seperti 
pembuat, bandar dan pengedar narkotika.

Kebijakan Bangsa Indonesia masih tetap menggunakan dan mempertahankan sanksi pidana mati sebagai salah satu jenis pidana yang terberat. Sanksi pidana mati tersebut dituangkan di dalam RUU KUHP Tahun 2015 Pasal 67 merupakan pidana pokok yang bersifat khusus dan selalu dicantumkan secara alternatif. Pasal 67 berbunyi :

Pidana mati merupakan pidana pokok yang bersifat khusus dan selalu diancamkan secara alternatif.

Sanksi pidana mati bersifat khusus yaitu pidana mati dicantumkan tersendiri untuk menunjukkan bahwa jenis pidana mati ini benar-benar bersifat khusus. Jika dibandingkan jenis pidana yang lain pidana mati merupakan jenis pidana yang paling berat. Pidana mati dikeluarkan dari stelsel pidana pokok yang diatur dalam ketentuan umum KUHP dan mencantumkannya sebagai pidana pokok yang bersifat khusus atau sebagai pidana eksepsional (perkecualian). Penempatan pidana mati terlepas dari paket pidana pokok dipandang penting, karena merupakan kompromi dari pandangan yang menolak (retensionis) dan yang menerima (abolisionis) hukuman mati. 28

Sanksi pidana mati selalu diancamkan secara alternatif dengan jenis pidana lainnya yakni pidana seumur hidup atau pidana prenjara paling lama 20 tahun. Pidana mati dikeluarkan dari stelsel pidana pokok

28 Abdur Rahim, "Hukuman Mati Problem Legalitas dan Kemanusiaan", Jurnal Trans Media, Malang, 2015, hlm. 28 yang diatur dalam ketentuan umum KUHP dan mencantumkannya sebagai pidana pokok yang bersifat khusus atau sebagai pidana eksepsional ( perkecualian ). Penempatan pidana mati terlepas dari paket pidana pokok dipandang penting, karena merupakan kompromi dari pandangan yang menolak (retensionis) dan yang menerima (abolisionis) hukuman mati. 29

b). Sanksi Pidana mati merupakan pidan alternatif karena pidana mati adalah pidana paling yang berat oleh karena itu harus selalu selalu diancamkan secara alternatif dengan jenis pidana lainnya yaitu pidana seumur hidup atau pidana penjara paling lama 20 ( dua puluh ) tahun. Susuai Pasal 87 RUU KUHP tahun 2015 bahwa :

Pidana mati secara alternatif dijatuhkan sebagai upaya terakhir untuk mengayomi masyarakat. Dalam penjelasan pasal tersebut diuraikan : Pidana mati ini ditekankan sifat kekhususan pidana mati yaitu hanya dapat dijatuhkan sebagai upaya terakhir untuk mengayomi masyarakat.

Sanksi pidana Mati dalam RUU KUHP tahun 2015 menganut Asas Keseimbangan. Asas Keseimbangan dituangkan dalam kosideran huruf c yang menyatakan dengan tegas bahwa dalam setiap penegakan hukum harus berlandaskan prinsip keseimbangan yang serasi antara dua kepentingan, yakni

a. Perlindungan terhadap harkat dan martabat manusia (HAM), dengan; 
b. Perlindungan terhadap

kepentingan dan ketertiban masyarakat.

Konsep KUHP baru dalam hukum pidana material sebagai pokok pemikirannya adalah Ide keseimbangan yang mencakup antara lain : ${ }^{30}$

a. Keseimbangan monodualistik antara kepentingan umum / masyarrakat dan kepentingan individu / perorangan.

b. Keseimbangan antara perlindungan / kepentingan pelaku tindak pidana dan korban tindak pidana, keseimbangan antara unsur atau faktor / objek (perbuatan lahiriah) dan subjektif.

c. Keseimbanagan antara kreteria formal dan material.

d. Keseimbanagan kepastian hukum, kelenturan / elastisitas / fleksibilitas dan kesadilan.

e. Keseimbangan nilai-nilai nasional dan nilai-nilai global / internasional / univerfsal.

Pidana pada hakikatnya hanya merupakan alat untuk mencapai tujuan. Dalam mengidentifikasi tujuan pemidanan, konsep bertolak dari keseimbangan dua sasaran pokok yaitu $:^{31}$ Perlindungan masyarakat dan perlindungan / pembianaan individu pelaku tindak pidana. Dua pokok pemikitan tersebut menitik beratkan pada perlindungan kepentingan masyarakat maka wajar konsep KUHP tetap mempertahankan jenis - jenis sanksi pidana yang berat yaitu pidana

\footnotetext{
${ }^{30}$ Barda Nawawi Arief, Pembaharuan Hukum Pidana Dalam Perspektif Kajian Perbanidngan, PT Citra Aditya Bakti, Bandung, 2005, hlm. 305

${ }^{31}$ Barda Nawawi Arif, Op.Cit, hal. 94
}

mati dan penjara seumur hidup. Upaya perlidungan masyarakat lebih menitik beratkan pada kepentingan masyarakat.

Menurut Barda Nawawi Arief dapat dimaklumi dengan alasan bahwa apabila dilihat dari tujuan pemidanaan, pidana mati pada hakikatnya bukan sarana utama/pokok untuk mengatur, menertibkan, dan memperbaiki individu/ masyarakat. Pidana mati hanya merupakan sarana terakhir/perkecualian. Hal ini diidentikkan dengan "amputasi/ operasi” di bidang kedokteran, yang pada hakikatnya juga bukan sarana/obat utama, melainkan hanya upaya perkecualian sebagai sarana/obat terakhir. Oleh karena itu dapat ditegaskan dalam Konsep bahwa "pidana mati secara alternatif dijatuhkan sebagai upaya terakhir untuk mengayomi masyarakat". ${ }^{32}$

Dari pasal-pasal dan penjelasan tersebut, maka sanksi pidana mati dapt diidetifikasikan kebijakan hukum pidan dalam konsep RUU KUHP Tahun 2015 sadalah sebagai berikut :

a. Pidana mati tetap dipertahankan sebagai pidana khusus / eksepsional dan tidak dapat dijatuhkan terhadap anak.

b. Pidana mati merupakan pidana alternatif yang digunakan sangat selektif dan sebagai upaya terakhir.

\section{Dasar-Dasar (Alasan) Sanksi Pidana Mati pada Tindak Pidana Narkotika}

Kejahatan Narkotika termasuk pembuat, bandar dan pengedar sangat

\footnotetext{
${ }^{32}$ Barda Nawawi Arief, “ Kapita Selekta Hukum Pidana, Cetakan ke-3. PT Citra Aditya Bakti, Bandung, 2013, hlm. 239
} 
membahayakan kehidupan manusia, masyarakat, bangsa dan negara sehingga termasuk kejahatan yang berat dan serius. Penyalahgunaan dan peredaran gelap Narkotika kian menjalar ke seluruh lapisan masyarakat dari tingkat elit sampai ke masyarakat desa. Narkotika merusak sumber daya manusia sebagai salah satu modal pembangunan nasional, oleh karena itu penyalahgunaan dan pemberantasan narkotika harus sungguh-sungguh ditindak tegas oleh para penegak hukum dan seluruh lapisan masyarakat untuk menyelamatkan Indonesia dari bahaya Narkotika. Dalam pemidanaan tindak pidana Narkotika bangsa Indonesia selalu mempertimbangkan Hak Asasi Manusia. HAM merupakan hak negatif (negative right) karena sifatnya yang kodrati dan universal, sehingga tidak memerlukan pengesahan, namun dalam kehidupan bermasyarakat, berbangsa dan benegara yang semakin komplek, pengaturan hukum terhadap HAM (positivization of right) akan memoperkuat posisi Indonesia sebagai negara hukum. ${ }^{33}$

Pertimbangan yang menjadi dasar penetapan UU Nomor 35 Tahun 2009 Tentang Narkotika dalam pengaturan tindak pidana narkotika adalah sebagai berikut :

a. Bahwa mengimpor, mengekspor, memproduksi, menanam, menyimpan, mengedarkan, dan/atau menggunakan Narkotika tanpa pengendalian dan pengawasan yang ketat dan saksama serta bertentangan dengan peraturan perundang-undangan

${ }^{33}$ Muladi, "Hak Asasi Manusia, Politik dan dan Sistim Peradilan “, Undip, Semarang, 1997, hlm. 6 merupakan tindak pidana Narkotika karena sangat merugikan dan merupakan bahaya yang sangat besar bagi kehidupan manusia, masyarakat, bangsa, dan negara serta ketahanan nasional Indonesia;

b. Bahwa tindak pidana Narkotika telah bersifat transnasional yang dilakukan dengan menggunakan modus operandi yang tinggi, teknologi canggih, didukung oleh jaringan organisasi yang luas, dan sudah banyak menimbulkan korban, terutama di kalangan generasi muda bangsa yang sangat membahayakan kehidupan masyarakat, bangsa, dan negara sehingga Undang- Undang Nomor 22 Tahun 1997 tentang Narkotika sudah tidak sesuai lagi dengan perkembangan situasi dan kondisi yang berkembang untuk menanggulangi dan memberantas tindak pidana tersebut;

Dalam penjelasan Umum disampaikan pertimbanganpertimbangan dalam penjabaran pasalpasal termasuk ada sanksi pidana mati antara lain :

a. Penyalahgunaan dan peredaran gelap Narkotika dapat mengakibatkan bahaya yang lebih besar bagi kehidupan dan nilainilai budaya bangsa yang pada akhirnya akan dapat melemahkan ketahanan nasional.

b. Tindak pidana Narkotika di dalam masyarakat menunjukkan kecenderungan yang semakin meningkat baik secara kuantitatif maupun kualitatif dengan korban yang meluas, terutama di kalangan anak-anak, remaja, dan generasi muda pada umumnya. 
c. Tindak pidana Narkotika tidak lagi dilakukan secara perseorangan, melainkan melibatkan banyak orang yang secara bersama-sama, bahkan merupakan satu sindikat yang terorganisasi dengan jaringan yang luas yang bekerja secara rapi dan sangat rahasia baik di tingkat nasional maupun maupun internasional.

d. Sanksi pidana diperberat dari undang-undang yamg lama. Sanksi diatur mengenai pemberatan sanksi pidana, baik dalam bentuk pidana minimum khusus, pidana penjara 20 (dua puluh) tahun, pidana penjara seumur hidup, maupun pidana mati.

Sanksi pidana mati hukum Indonesia secara yuridis mempunyai dasar hukum yang kuat. Tidak ada satu peraturan perungang-undangan : UUD NRI Tahun 1945, KUHP, UU No. 35 Tahun 2009 Tentang Narkotika dan UU No. 39 Tahun 1999 Tentang HAM yang menyebutkan dasar pembuktian sanksi pidana mati tersebut sehingga eksistensinya (kenyataan yang dimmiliki) menimbulkan perelisihan. Sehingga sanksi pidana mati tersebut masih sangat penting untuk dipertahankan sebagai upaya terakhir dalam pemidanaan mewujutkan Keadilan, Kepastian dan kemanfaatan. Sanksi pidana mati sudah pantas atau selayaknya deberikan untuk pelaku tindak pidana narkotika dengan kategori pembuat, bandar dan pengedar. Kejahan pembuat, bandar dan pengedar narkotika merupakan kejahatan yang berat, serius, merusak generasi muda,dan mengacam kehidupan manusia.
Tidak logis jika menyatakan bahwa sanksi pidana mati tidak membuat jera atas tindak pidana tersebut. Sanksi pidana mati dijatuhka kepada pelaku tindak pidana yang melakukan kejahata berat dan serius, sebagai benteng / upaya terakhir untuk melindungi masyarakat dan bangsa Indonesia. Terlebih lagi ada argumen yang menyatakan bahwa sanksi pidana mati itu hak Tuhan yang tidak boleh dilakukan oleh manusia untuk menvosis mati seseorang. Dasar alasan ini menurut penulis tidak benar karena Tuhan sendiri di dalam firmannya (dalam kitab Injil maupun Al Qur'an) memberikan kebolehan sanksi pidana mati.

Sebagaimana Firman-Nya sebagai berikut :

a). Hai orang-orang yang beriman, diwajibkan atas kalian qisas berkenaan dengan orang-orang yang dibunuh; orang merdeka dengan orang merdeka, hamba dengan hamba, dan wanita dengan wanita. Maka barang siapa yang mendapat suatu pemaafan dari saudaranya, hendaklah (yang memaafkan) mengikuti dengan cara yang baik, dan hendaklah (yang diberi maaf) membayar (diat) kepada yang memberi maaf dengan cara yang baik (pula). Yang demikian itu adalah suatu keringanan dari Tuhan kalian dan suatu rahmat. Barang siapa yang melampaui batas sesudah itu, maka baginya siksa yang sangat pedih. Dan dalam qisas itu ada (jaminan kelangsungan) hidup bagi kalian, hai orang-orang yang berakal, supaya kalian bertakwa (QS 2:178179).

b) Dan janganlah kamu membunuh jiwa yang diharamkan Allah 
(membunuhnya) melainkan dengan suatu (alasan) yang benar." (QS. AlIsra':33)

c) "Dan Janganlah kamu membunuh jiwa yang diharamkan Allah (membunuhnya) melainkan dengan suatu (sebab) yang benar." (QS. alAn'am : 151).

d). Injil : Kitab Wahyu $22: 12$

“ sebagai kitab terakhir, kita menemukan perkataan ini dari Tuhan kita: "Sesungguhnya Aku datang segera dan Aku membawa upah-Ku untuk membalaskan kepada setiap orang menurut perbuatannya "

e). Injil : Kitab Korintus 5 :10

"Sebab kita semua harus menghadap takhta pengadilan Kristus, supaya setiap orang memperoleh apa yang patut diterimanya, sesuai dengan yang dilakukannya dalam hidupnya ini, baik ataupun jahat.

f). Injil : Kejadian 9 :6 sangat jelas berkata:

"Siapa yang menumpahkan darah manusia, darahnya akan tertumpah oleh manusia, sebab Allah membuat manusia itu menurut gambarNya sendiri."

g). Injil : Kejadian 4:14

"Allah memberikan kuasa untuk menghukum mati kepada pemerintahan manusia ".

\section{B. Penerapan Sanksi Pidana Mati Terhadap Pelaku Tindak Pidana Narkotika}

Dalam memori penjelasan disebutkan bahwa negara berhak untuk menjalankan semua peraturan atau ketentuan pasal-pasal tersebut di atas, termasuk pidana mati sebagai “ kriterium keharusan " dengan maksud negara dapat memenuhi kewajibannya untuk menjaga ketertiban hukum dan kepentingan umum.

Andi Hamzah menyatakan bahwa hukuman mati adalah pidana yang terberat dari semua pidana, sehingga hanya diancamkan kepada kejahatankejahatan yang amat berat saja yaitu perbuatan yang mengakibatkan matinya orang lain dan perbuatan-perbuatan yang dapat menimbulkan bahaya besar atau mempunyai akibat-akibat yang berpengaruh besar terhadap perikehidupan manusia, kejahatan yang mengancam kehidupan manusia dan kehidupan negara di bidang politik, ekonomi, sosial, budaya serta

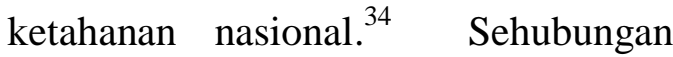
dengan permasalahan yang diajukan, maka penulis menyampaikan sebuah perkara tindak pidana narkotika yang sanksi pidananya divonis pidana mati oleh Pengadilan Tinggi adalah sebagai berikut :

Putusan Pengadilan Tinggi Nomor 303/Pid/2015/PT.DKI Tahun 2016 ZAINI JAMALUDIN Als ZAINI Bin JAMALUDIN.

Nomor : $\quad$ 303/Pid/2015/PT.DKI;

Tingkat proses : Banding.

Tanggal : 31 Desembere 2015.

Amar : Menguatkan

M E N G A D I L I - Menerima permintaan banding dari Terdakwa dan Penuntut Umum ;

- Menguatkan putusan Pengadilan Negeri Jakarta Barat Nomor 1118/Pid.Sus/2015 /PN.JKT.BRT tanggal 19 Nopember 2015 yang dimintakan banding tersebut, dengan perbaikan sekedar mengenai status barang bukti No.

${ }^{34}$. Hamzah, Andi dan Rahayu, Siti, "Suatu Tinjauan Ringkas Sistem Pemidanaan di Indonesia ", Akademika Pressindo, Jakarta, 1983, hlm. 32 
1, sehingga amar selengkapnya sebagai berikut ;

- Menyatakan Terdakwa ZAINI JAMALUDIN Als ZAINI Bin JAMALUDIN terbukti secara sah dan meyakinkan bersalah melakukan tindak pidana :-------

1. Permufakatan Jahat Untuk Melakukan Tindak Pidana Narkotika Yang Dilakukan Dengan Tanpa Hak Dan Melawan Hukum Menerima, Menjadi Perantara Dalam Jual Beli, Atau Menyerahkan Narkotika Golongan I Dalam Bentuk Tanaman Beratnya Melebihi 1 ( Satu ) Kilogram dan-----

Catatan Amar :

" Tanpa hak dan melawan hukum menguasai dan memiliki narkotika golongan I bukan tanaman " ----

- Menjatuhkan pidana terhadap Terdakwa ZAINI JAMALUDIN Als ZAINI Bin JAMALUDIN dengan “ pidana MATI ";

- Menetapkan Terdakwa tetap berada dalam tahanan ; -----

- Menyatakan barang bukti berupa :

1. Berita Acara Pemusnahan barang bukti tanggal 11 Maret 2015, barang bukti 33 (tiga puluh) karung besar yang berisi Narkotika Golongan I dalam bentuk tanaman (ganja) dengan berat brutto 1.332.000 gram (dimusnahkan 1.331.990 gram) dan untuk dikirim ke Laboratorium sebanyak 10 gram dengan hasil Pemeriksaan
Laboratoris Kriminalistik No. LAB : 0287/NNF/2015 tanggal 28 Januari 2015 , disimpulkan bahwa barang bukti daun-daun kering dengan berat netto9,7765 gram adalah benar Ganja terdaftar dalam Golongan I Nomor urut 8 Lampiran Undang Undang Republik Indonesia No. 35 tahun 2009 tentang narkotika. Dan ---Tetap terlampir dalam berkas perkara ;--------

2. 1 (satu) buah pipet yang masih berisi Narkotika Gol. I bukan tanaman (shabu),

1 (satu) buah bong atau alat hi sap yang terbuat dari botol hisap yang terbuat dari botol aqua dan 2 (dua) buah sedotan kecil.

- dirampas untuk dimusnahkan;

- barang bukti :

- 1 (satu) unit hand phone merk Nokia type 105 warna biru berikut simcard Simpati AS dengan nomor 082304351111.

- 1 (satu) unit hand phone merk Nokia type RM769 warna merah berikut simcard Simpati AS dengan nomor 081362804279 .

- 1 (satu) unit mobil Tronton Fuso FU 415 N, warna silver. No. Pol. B 9165 TE, tahun 1999 .

- I (satu) unit mobil Tronton Fuso FU $415 \mathrm{~N}$, warna putih. No. Pol. B 9136 ZB tahun 1998. -

- 1 (satu) unit Tronton Fuso, warna biru No. Pol. B 9914 
QN.--- - 1 (satu) mobil penumpang model Jeep LC HDTP, merk Mitsubshi, type PJR SP 2.5 D EXCAX2AT, No. Pol. B 1597 PJB, tahun 2010.

dirampas untuk Negara ;----

- Membebankan biaya perkara ini kepada Terdakwa dalam kedua tingkat pengadilan yang dalam tingkat banding ditetapkan sebesar Rp.2.000.- (dua ribu rupiah) ;--

\section{Hakim Ketua}

JOHANES SUHADI, SH

Dari kasus tindak pidana narkotika di atas :

$\begin{array}{lrr}\text { Putusan } & \text { Pengadilan } & \text { Tinggi } \\ \text { Nomor } & \text { 303/Pid/2015/PT.DKI } \\ \text { Tahun } & 2016 \\ \text { terdakwa } & \text { a.n. } & \text { ZAINI } \\ \text { JAMALUDIN } & \text { pengedar } \\ \text { narkotika } & \end{array}$

Eksistensi pidana mati, sebagai sanksi pidana di dalam Pasal 10 KUHP dan RUU KUHP Tahun 2015 ditinjau dari sejarah hukum merupakan kebijakan serta politik bangsa Indonesia yang berdasarkan ide-ide dasar Ketuhanan Yang Maha Esa (Hukum Tuhan di dalam Kitab Injil maupun Al - Qur'an) untuk mewujutkan Kepastian, Keadilan dan Kemanfatan hukum. Menurut Pujiyono, ada tiga alasan utama diberlakukannya pidana mati di Indonesia, yaitu alasan berdasarkan 3 (tiga) faktor antara lain $:^{35}$

35 Pujiyono, “Kumpulan Tulisan Hukum Pidana “, Mandar Maju, Bandung, 2007, hlm. 2
1. faktor rasial (Hukum Pidana merupakan warisan atau peninggalan )

2. berdasarkan faktor ketertiban umum, karena Indonesia terdiri dari banyak suka dan bahasa; dan

3. alasan berdasarkan hukum pidana dan kriminologi yang berarti untuk mengakhiri atau upaya terakhir kejahatan yang berat dan serius dan pencegahan tehadap orang lain.

Perbuatan yang dilakukan oleh terdakwa juga bertentangan dengan Pasal 7 Undang-Undang No. 35 Tahun 2009 tentang Narkotika yaitu bahwa bahwa "Narkotika Golongan I hanya dapat digunakan untukkepentingan pengembangan ilmu pengetahuan dan dilarang untuk kepentingan lainnya" danjuga bertentangan dengan pasal 16 yaitu bahwa "mengeksportir narkotika harus memiliki surat persetujuan eksport untuk setiap kali melakukan eksport narkotika dari mentri kesehatan " dan ternyata terdakwa tidak memilikinya. Menurut pandangan penulis, sanksi pidana mati merupakan kepastian hukum, keadilan dan kemanfatan, meskipun menimbulkan pro dan kontra. Perbedaan itu selalu muncul karena dalam masyarakat yang heterogen sehingga selalu ada pendapat-pendapat yang berbeda. Negara Indonesia berdasarakan Pancasila sebagai falsafah bangsa yang Berketuhanan Yang Maha Esa, maka ide-ide dasar juga dati tuhan termasuk sanksi pidana mati tetap depertahankan dan deperlukan guna menjaga keamanan dan ketrentraman rakyat bangsa Indonesia.

Sanksi pidana mati dalam Undang Undang No. 35 Tahun 2009 tentang 
Narkotika adalah masih relevan untuk diterapkan karena kejahatan narkotika termasuk kejahatan extra ordinary crime (kejahatan yang luar biasa) atau berat dan serius. Dengan adanya sanksi pidana mati dalam Undang-Undang Narkotika merupakan benteng terakhir perlindungan kepada bangsa dan negara dari kejahatan perdagangan dan peredaran narkotika. Sehingga satusatunya cara untuk memutus mata rantai peredaran gelap narkotika adalah dengan menjatuhkan sanksi pidana mati kepada pelaku tindak pidana narkotika. " Legal policy atau (garis kebijakan resmi) tentang hukum yang akan di berlakukan baik dengan pembuatan hukum baru maupun dengan penggatian hukum lama, dalam rangka mencapai tujuan negara. ${ }^{36}$

Masyarakat mayoritas memeluk agama Islam. Faham ketuhananlah yang banyak menjadi orientasi atau ide - ide dasar pedoman hidup dan pandangan dalam mengatur kemanan dan ketertiban masyarakat dan bernegara. Hukum Tuhan yang tercantum dalam kitab suci ( Kristen atau Islam) dianggap hukum yang pasti benar dan pasti adilnya. Sesuai Surah dengan kitab Al Qur'an surah AlAn'am (6) ayat 115 senada surah Ibrahim (14) ayat 52 Jo firmanNya :

"Dan telah sempurnalah kalimat (firman) Tuhanmu dengan benar dan adil. Tidak ada yang dapat mengubah firmanNya. Dan Dia Maha mendengar, Maha mengetrahui, Surah Al-A'raaf (7) ayat 137 / Surah AL-Hijr (15) ayat 1;

“ .... Dan telah sempurnalah firman Tuhanmu yang baik itu ( sebagai janji ) untuk bani Israil disebabkan kesabaran mereka.

\footnotetext{
${ }^{36}$ Moh. Mahfud MD, Op.Cit, hlm.1
}

\section{Kesimpulan}

1. Kebijakan Sanksi pidana mati terhadap tindak pidana narkotika merupakan salah satu eksistensi kedaulaulatan bangsa Indonesia sehingga tetap mempertahankan dan memerlukannya. Tindak pidana narkotika merupakan kejahatan yang berat dan serius, sangat merugikan bangsa dan negara dan merupakan bahaya yang sangat besar bagi kehidupan manusia, masyarakat, bangsa, dan negara serta ketahanan nasional Indonesia. Penjatuhan sanksi pidana mati merupakan benteng terakhir untuk menjaga keamanan dan ketertiban bangsa dan negara Indonesia dan sebagai amputasi jaringan kejahata narkotika.

2. Penerapan sanksi pidana mati terhadap tindak pidana narkotika diberikan kepada penjahat narkotika sebagai Pembuat, bandar dan pengedar. Bahwa sanksi pidana mati yang ada dalam Undang-Undang No.35 Tahun 2009 Tentang Narkotika adalah masih sangat relevan untuk diterapkan, karena kejahatan narkotika termasuk kedalam kejahatan berat dan serius serta mengacam kehidupan manusia.

\section{Saran}

1. Bangsa Indonesia sebagai bangsa yang berketuhanan Yang Maha Esa bagian dari bangsa-bangsa yang beradab dalam hal ini Pemerintah harus tetap mempertahankan dan menerapkan sanksi pidana mati dari sistem hukum yang berlaku. Teori atau konsep apapun atau yang manapun yang lebih baik kalau Tuhan sudah 
memberikan firmannya di dalam kitabNya ( Injil atau Al - Qur'an ) dari kebijakan adanya sanksi pidana mati. Kebijakan adanya sanksi pidana mati merupakan salah satu eksistensi kedaulatan bangsa Indonesia, serta memiliki makna yang sangat penting dari sisi upaya perlindungan hak asasi manusia, yang mana dibatasi hak asasi orang lain oleh hukum dan kekuasaan Negara.

2. Para penegah hukum tidak perlu ragu-ragu atau takut dari kekuasaan lain atau pihak-pihak tertentu dalam menjatukkan sanksi pidana mati terhadap pelaku tindak pidana narkotika sebagai pembuat, bandar dan pengedar karena sudah sesuai dengan peraturan perundang - undangan yang berlaku. Sanksi pidana mati sudah sesuai dengan Peraturan perundang - undangan yang berlaku ( UUD NRI Tahun 1945, KUHP, UU No. 35 Tahun 2009 Tentang Narkotika dan UU No. 39 Tahun 1999 Tentang HAM ).

\section{DAFTAR PUSTAKA}

A. Gunawan Setiaji, 1993, "Hak Asasi Manusia Berdasarkan Ideologi Pancasila“, Kanisius, Yogjakarta. Abdur Rahim, Muhammad H, 2015, Satrio Wirataru, "Hukuman Mati Probem Legalitas", Intrans Institute, Malang,

Barda Nawawi Arief, 2014, "Masalah

Penegakan Hukum dan Kebijakan
Hukum Pidana dalam

Penanggulangan Kejahatan “

Kencana Prenada Media Group, Jakarta.

------, 2014, “Bunga Rampai Kebijakan

Hukum Pidana“ Kencana

Prenadamedia G, Jakarta.

Gunawan Setiardja, 2014, “ Masalah

Penegakan Hukum dankebijakan

Hukum Pidana Dalam

Penanggulangan Kejahatan ",

Kencana Prenadamedia G,

Jakarta.

Hamzah, Andi dan Rahayu, Siti, 1983, "Suatu Tinjauan Ringkas Sistem Pemidanaan di Indonesia“, Akademika Pressindo, Jakarta.

Muladi, 1997, "Hak Asasi Manusia,

Politik dan Sistem Peradilan

Pidana“, Penerbit Universitas

Diponegoro, Semarang.

Todung Mulya Lubis \& Alexander Lay, 2009, “Kontroversi Hukuman Mati“, Kompas Media, Jakarta.

\section{Sumber Lain :}

http://www.mahkamahkonstitusi.go.id/ 